\title{
A psoriasisos betegek kezelésében megfigyelhetô változások az elmúlt évtizedben a Debreceni Egyetem Orvos- és Egészségtudományi Centrum Bôrgyógyászati Klinikáján és a területi járóbeteg szakrendeléseken
}

\section{Changes in the treatment of psoriatic patients in the last decade at the Department of Dermatology, University of Debrecen Medical and Health Science Center and at the outpatient clinics}

\author{
GÁSPÁR KRISZTIÁN DR., NAGY MÁRIA DR., HERÉDI EMESE DR., NAGY GEORGINA, \\ SZEGEDI ANDREA DR.
}

\begin{abstract}
Debreceni Egyetem OEC, Bôrgyógyászati Klinika, Bőrgyógyászati Allergológia Tanszék, Debrecen, Magyarország
\end{abstract}

\section{ÖSSZEFOGLALÁS}

A psoriasis vulgaris szisztémás gyulladással járó, krónikus immun-mediált betegség, mely elsösorban a bört érinti. A börgyógyász terápiás palettáján a lokális készítmények mellett szisztémás gyógyszeres kezelés, fényterápia és biológiai terápia érhetố el. Jelen keresztmetszeti vizsgálatban a szerzók bemutatják, és elemzik a psoriasis terápiák alkalmazásának változásait a mindennapi gyakorlatban a Debreceni Egyetem Orvos-és Egészségtudományi Centrum Börgyógyászati Klinikán, valamint hazai szakrendelökben. A pathomechanizmus jobb megismerésével, és a betegség megítélésében bekövetkezett paradigmaváltással átalakultak a terápiás protokollok, valamint új terápiás beavatkozások is megjelentek, melyek eredményei a hazai kezelésben is fordulatot eredményeztek.

Kulcsszavak: psoriasis - kezelések változása

\section{SUMMARY}

\begin{abstract}
Psoriasis is a chronic immune-mediated disease with chronic inflammation, which affects mainly the skin. For the dermatologist in the treatment of psoriasis local agents, systemic conventional treatment, phototherapy, and biologics are available. In the present study authors report and analyze the changes in the use of psoriasis treatment in practice at the Department of Dermatology University of Debrecen, Medical and Health Science Centre, and in specialized ambulances. The therapeutic protocols have been improved and new therapeutic options are introduced due to the changes in the approach of the disease that have promoted modifications in the treatment in our country as well.
\end{abstract}

Key words:

psoriasis - treatment changes
Az intenzív patogenetikai kutatásoknak köszönhetôen bizonyított, hogy a psoriasis vulgaris elsósorban a bőrt érintő krónikus, nem fertőző, immun-mediált betegség, mely szisztémás gyulladással jár.

A betegség az iparilag fejlett országokban a népesség 1,5-2\%-át érinti, multifaktoriális, poligénes öröklődést mutat (1). A psoriasis manifesztálódásában a genetikai tényezők mellett környezeti faktorok játszanak szerepet (2). A betegség bármely életkorban kialakulhat, de a tünetek kezdete alapján két csoportot lehet megkülönböztetni. Az 1-es típusra a humán leukocyta antigén (HLA) Cw6 és HLA-DR7 génekkel való kapcsolat, családi hal- mozódás és viszonylag korai kezdet (40 éves kor előtt) jellemző, míg a 2-es típust a 40 év feletti kezdet jellemzi és a HLA génekkel való kapcsolat, továbbá családi halmozódás ritkábban mutatható ki (2-5). A betegséget a klinikai tünetek és az életminőségre gyakorolt hatása alapján enyhe, és középsúlyos-súlyos formákra oszthatjuk, és kezelésében a lokális terápia mellett hagyományos (fényterápia, konvencionális szisztémás terápia), és biológiai terápia alkalmazható (1). Az alkalmazott kezelés formáját elsősorban a bőrtünetek súlyossága, az ízületi és körömérintettség jelenléte határozza meg és kiválasztásánál fontos szempont még a korábbi kezelések ha-

Levelezô szerző: Dr. Gáspár Krisztián, Debreceni Egyetem OEC Bőrgyógyászati Klinika, 4032 Debrecen, Nagyerdei krt. 98. e-mail: nurk7@freemail.hu 
tásossága, a komorbiditások jelenléte, egyéb gyógyszerek szedése, valamint a beteg életmódja.

\section{Célkitúzések}

Tanulmányunk során azt vizsgáltuk, hogy a psoriasisról alkotott klinikai definíció megváltozása valamint a betegség hátterének pontosabb megismerése vajon okozott-e változást a terápiás algoritmusok alkalmazásában a bőrgyógyászati gyakorlatban.

A kérdés megválaszolásához elsődleges célkitűzésünk volt a Debreceni Egyetem Orvos- és Egészségtudományi Centrum (DEOEC) Bőrgyógyászati Klinikáján 2005. 09. 01.-2005. 11. 30. és 2010. 09. 01.-2010. 11. 30. időszakok alatt psoriasis miatt kezelt betegek adatainak összegyújtése és feldolgozása, valamint az adatok segítségével a kezelések jellemzőinek, változásainak bemutatása és analízise.

Másodlagos célkitûzés volt a kapott eredmények összevetése a hazai bórgyógyászati járóbeteg szakrendelések legfrissebb (2010) hasonló paramétereket vizsgáló adataival, melyet a DEOEC Bőrgyógyászati Klinika által szervezett, psoriasisos betegeken végzett adatgyújtés során nyertünk.

\section{Adatok és módszerek}

Az adatgyújtés a DEOEC Bőrgyógyászati Klinikán, a számítógépes orvosi adatbázisból történt. A 2005. 09. 01. - 2005. 11. 30., valamint 2010. 09. 01. - 2010. 11. 30. közötti időszakokban a Psoriasis Szakrendelésen járóbetegként jelentkezett, valamint fekvőbeteg ellátásban részesült, L4000-L4090 Betegségek Nemzetközi Osztályozása (BNO) kódú diagnózissal rendelkezó betegek minden bőrgyógyászati vonatkozású dokumentációját áttekin-

\begin{tabular}{|l|c|c|c|}
\hline & DEOEC 2005 & DEOEC 2010 & Szakrendelők 2010 \\
\hline Betegszám (db) & 224 & 403 & 383 \\
\hline Átlagéletkor (év) & 49,6 & 48,1 & 49,4 \\
\hline $\begin{array}{l}\text { Psoriasis fennállása } \\
\text { (év) }\end{array}$ & 13,7 & 14,3 & 16,5 \\
\hline $\begin{array}{l}\text { Nemek aránya } \\
\text { (férfi:nô) }\end{array}$ & $54: 46$ & $53: 47$ & $53: 47$ \\
\hline $\begin{array}{l}\text { Középsúlyos-súlyos } \\
\text { betegek (\%) }\end{array}$ & 56 & 63 & 46 \\
\hline \multicolumn{2}{|c|}{ 1. táblázat }
\end{tabular}

A vizsgálati célparaméterek változása a psoriásisos betegpopulációban a DEOEC Bőrgyógyászati Klinikán 2005-ben, 2010-ben, és a bőrgyógyászati szakrendeléseken 2010-ben

\section{Betegadatok}

A kutatás során nyert részletes betegadatokat az 1. táblázat ismerteti. A Bőrgyógyászati Klinika eredményeit a vidéki szakrendelők adataival összehasonlítva több, mint 1000 beteg adatait vizsgáltuk. A betegek átlagéletkora, a betegség fennállásának átlagos ideje és a nemek aránya közel azonos volt a 3 vizsgálatban, nem tapasztaltunk szignifikáns eltérést ezen paraméterekben az egyes vizsgálati időpontokban. Fontos különbség volt azonban, hogy míg a területi szakrendelőkben elsősorban enyhe psoriasisos tünetekkel jelentkezó betegeket kezeltek (a középsúlyos-súlyos betegek aránya a szakrendelőkben 46\%), addig a DEOEC Bőrgyógyászati Klinikán szignifikánsan magasabb arányban láttunk el középsúlyos-súlyos tünetekben szenvedô betegeket (2005-ben 56\%*p<0.05; 2010-ben $63 \% * * p<0.01)$. Továbbá a klinikán a két vizsgálati periódust összehasonlítva a betegszám, és a középtettuik. Az elsố idôperiódusban 224, a második időszakban 403 beteg adatait dolgoztuk fel. A felhasznált információk a betegek nemére, életkorára, betegség fennállási idejére és az alkalmazott gyógykezelésre vonatkoztak. A terápiás lehetőségeket 4 alcsoportba sorolva tanulmányoztuk: lokális terápia, szisztémás terápia (ezen belül acitretin, cyclosporin $\mathrm{A}$, methotrexát), fényterápia, biológiai terápia. A psoriasis súlyosságát és kiterjedését leíró Psoriasis Area and Severity Index (PASI) alkalmazása jelen vizsgálatban nem jött szóba, mert a feldolgozott betegek már kezelt állapotban voltak, ezért a betegek csoportosítása aszerint történt, hogy a vizsgálat időpontjában aktuálisan milyen kezelésben részesültek. Akik csak lokális kezelésben részesültek a vizsgált időszakban, azok az enyhe esetek csoportját alkották, míg a középsúlyos-súlyos kategóriába azok a betegek kerültek, akik a vizsgált időszakban, a lokális terápia mellett szisztémás gyógyszeres kezelésben, fénykezelésben, vagy biológiai terápiában részesültek.

A magyarországi bőrgyógyászati járóbeteg szakrendelőkben 2010ben alkalmazott terápiák ismertetéséhez szükséges adatokhoz a DEOEC Bőrgyógyászati Klinika által szervezett és irányított, széleskörû, kérdőívvel végzett felmérés eredményeinek áttekintése révén jutottunk. A felmérésben 32 bőrgyógyász 383 psoriasisban szenvedő betege vett részt. Az egyes Bőr- és Nemibeteg Gondozó Intézetek elsô 10-12, random érkező psoriasisos betegével kitöltetett kérdőívek révén szerzett információk 2010. szeptember 1. - 2010. november 30. időszakban születtek. Az információk kezelése anonim módon történt. A felhasznált adatok a betegek nemére, életkorára, betegség fennállási idejére és az alkalmazott gyógykezelésre vonatkoztak.

Az adatok feldolgozása, statisztikai kiértékelése és összehasonlítása Fischer-féle egzakt-próba révén történt, 5\%-os szignifikancia szinttel dolgozva. súlyos-súlyos betegek arányának erốteljes, de nem szignifikáns növekedése volt megfigyelhető. E tekintetben 2005 vizsgált időszakában 224 beteg $56 \%$-a, míg 5 évvel késốbb már 403 beteg csaknem 2/3-a (63\%) szenvedett a betegség középsúlyos-súlyos formájában.

\section{Alkalmazott kezelések változása és ezek összehasonlítá- sa az egyes vizsgálóhelyeken}

A psoriasis általános kezelésére jellemzô, hogy a betegek egyszerre több terápiában is részesülhettek (kombinált terápia), ilyen esetben az alkalmazott terápiára vonatkozó adatokat minden egyes terápiánál külön feltüntettük.

1. Változások összehasonlítása a DEOEC szakrendelésén 2005. és 2010. vizsgált periódusaiban

A DEOEC Bőrgyógyászati Klinikán 2005 vizsgált időszakában a páciensek 4/5-e (80\%) részesült lokális kezelésben (1A. ábra). Ugyanitt 2010-ben már csak a betegek $68 \%$-a részesült helyi kezelésben (1B. ábra). Eszerint mind 2005-ben, mind 2010-ben a pikkelysömörös betegek kezelésében fontos szerepet kaptak a helyi kezelések, de azok használatának aránya szignifikánsan csökkent 2010re (2. táblázat). 
Míg 2005-ben a Bőrgyógyászati Klinikán a középsúlyos-súlyos psoriasisban szenvedő betegek esetében a fényterápia volt a leggyakrabban választott kezelési metódus (32\%) (1A. ábra), addig ez az arány szignifikánsan kevesebb mint felére csökkent (14\%) 2010-re (1B. ábra), alkalmazása jelentôsen háttérbe szorult (2. táblázat).

A 2005-ös klinikai adatokat vizsgálva szembetúnik, hogy a fényterápia mellett hasonlóan kiemelt szerep jutott a középsúlyos-súlyos betegek kezelésében a hagyományos szisztémás gyógyszeres terápiának (31\%) (1A. ábra). Ezek közt vezetô szerep jutott az acitretinnek (20\%), míg a methotrexát és a cyclosporin A csak kisebb százalékban (9\%, illetve 2\%) képviseltette magát. Ugyanez az arány 2010-re 38\%-ra nôtt, azaz a primer terápiás megoldást jelentette a középsúlyos-súlyos psoriasisos betegek kezelésében (1B. áb$\mathrm{ra}$ ). Az egyes hagyományos szisztémás gyógyszeres terápiák alkalmazásának aránya, azonban jelentősen megváltozott 2010-re. Az acitretin háttérbe szorult, és szignifikánsan nagyobb arányban kaptak a betegek methotrexátot (22\%), míg a cyclosporin A alkalmazási gyakorisága nem mutatott szignifikáns eltérést a két idôpontban (2. táblázat).

A biológiai terápia használatát tekintve is szignifikáns növekedés volt megfigyelhető a klinikai adatokban 2010-re. Míg 2005-ben biológiai terápiában csak a betegek $1 \%$-a részesült ( $1 A$. ábra), addig 2010-re a hagyományos gyógyszeres terápia vezetô szerepe mellett új, széles körben elérhető terápiás lehetőségként jelent meg a biológiai terápia (20\%) (1B. ábra) (2. táblázat).

2. Terápiás különbségek a DEOEC szakrendelésén és a területi szakrendelökben 2010-ben

A DEOEC Bőrgyógyászati Klinikán 2010-ben a betegek 68\%-a részesült helyi kezelésben (1B. ábra), a vidéki szakrendelőkben ugyanakkor a helyi kezelés aránya ( $89 \%)$, a betegek klinikai súlyosságának megfelelően, szignifikánsan magasabb volt (2. táblázat), és jelentősen meghaladta az egyéb terápiás lehetőségek alkalmazását (1C. ábra).

Míg 2010-ben a Bőrgyógyászati Klinikán a középsúlyos-súlyos psoriasisban szenvedő betegek esetében a fényterápia alkalmazása jelentősen háttérbe szorult (1B. ábra), addig a vidéki szakrendelőkben szignifikánsan ma-

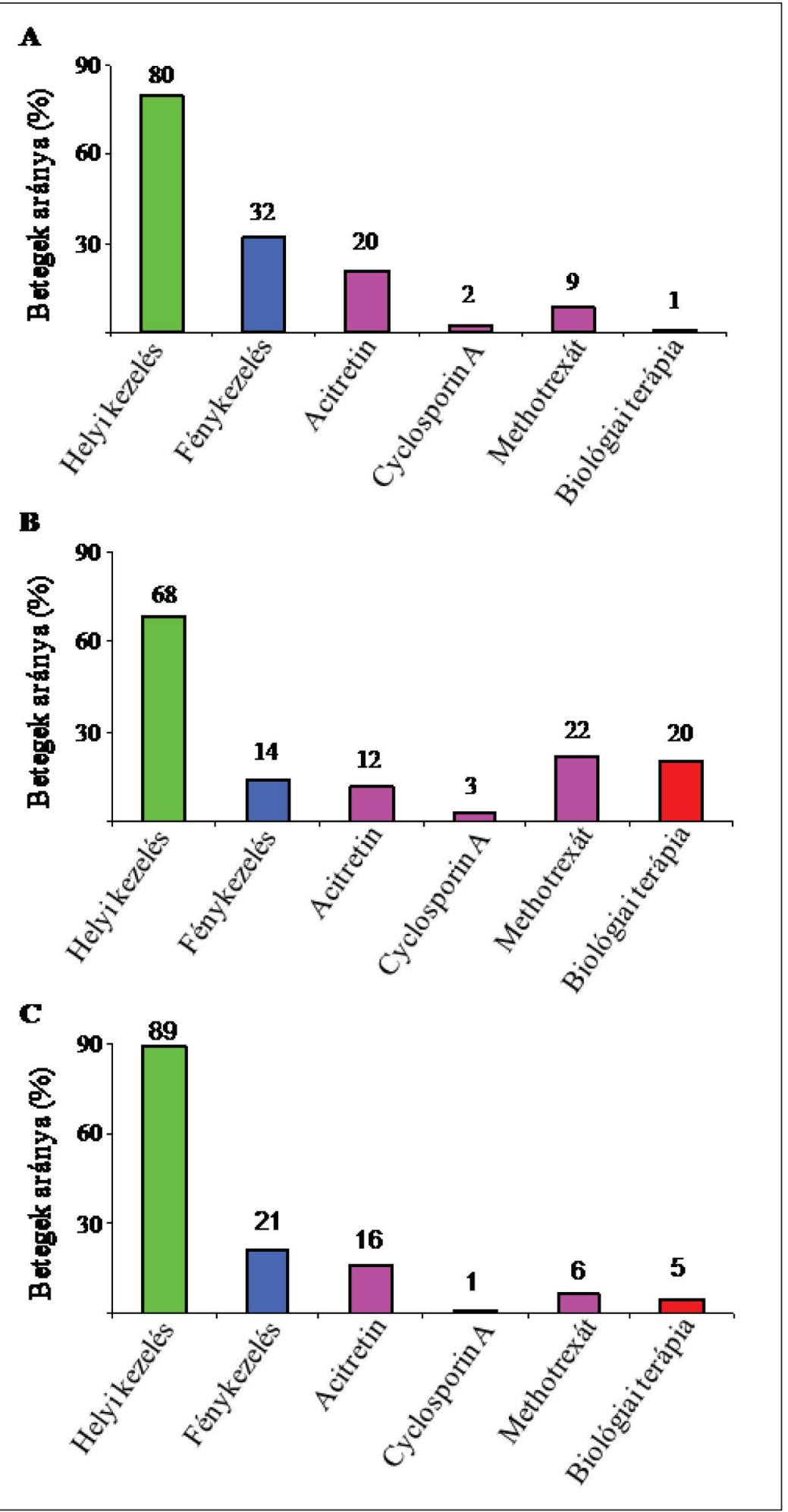

1. ábra

Az egyes terápiás beavatkozásban részesülő psoriásisos betegek aránya a DEOEC Bőrgyógyászati Klinikán 2005-ben (A), 2010-ben (B), és a bőrgyógyászati szakrendeléseken 2010-ben (C)

gasabb arányban (2. táblázat) a fényterápia volt a vezetô szisztémás terápia (21\%) (1C. ábra).

Az egyes hagyományos szisztémás gyógyszeres terápiák alkalmazásának arányát a DEOEC 2010-es adataiban (1B. ábra) és a vidéki szakrendelókben (1C. ábra) vizs- 


\begin{tabular}{|l|c|c|c|c|c|}
\hline & $\begin{array}{c}\text { DEOEC) } \\
2005(\%)\end{array}$ & $\begin{array}{c}\text { DEOEC } \\
2010(\%)\end{array}$ & $\begin{array}{c}\text { Szakrendelők } \\
2010(\%)\end{array}$ & $\begin{array}{c}\text { Szignifikancia DEOEC } \\
2005 \text { és 2010 adatai között }\end{array}$ & $\begin{array}{c}\text { Szignifikancia DEOEC és } \\
\text { szakrendelök 2010 adatai között }\end{array}$ \\
\hline Helyi kezelés & 80 & 68 & 89 & $* * * \mathrm{p}<0.005$ & $* * * \mathrm{p}<0.005$ \\
\hline Fénykezelés & 32 & 14 & 21 & $* * * \mathrm{p}<0.005$ & $* * \mathrm{p}<0.01$ \\
\hline Acitretin & 20 & 12 & 16 & $* * * \mathrm{p}<0.005$ & $\mathrm{n} . \mathrm{sz}$. \\
\hline Cyclosporin A & 2 & 3 & 1 & $\mathrm{n} . \mathrm{sz}$. & $\mathrm{n} . \mathrm{sz}$. \\
\hline Methotrexát & 9 & 22 & 6 & $* * * \mathrm{p}<0.005$ & $* * * \mathrm{p}<0.005$ \\
\hline Biológiai terápia & 1 & 20 & 5 & $* * * \mathrm{p}<0.005$ & $* * * \mathrm{p}<0.005$ \\
\hline
\end{tabular}

2. táblázat

A psoriásis terápiák betegeinek százalékos eloszlása és az eredmények összehasonlítása a DEOEC Bőrgyógyászati Klinikán 2005-ben, 2010-ben, és a bőrgyógyászati szakrendeléseken 2010-ben (n.sz.: nem szignifikáns)

gálva megfigyelhető, hogy a methotrexátot szignifikánsan gyakrabban használták a klinikán, mint a szakrendelőkben, ugyanakkor az acitretin és cyclosporin A használatában nem volt szignifikáns különbség a 2 vizsgálati hely között (2. táblázat).

A biológiai terápia használatát tekintve természetesen szignifikánsan magasabb volt a kezelt betegek aránya 2010-ben a biológiai centrumban, a klinikán (1B. ábra), mint a szakrendelőkben (1C. ábra) (2. táblázat).

\section{Megbeszélés}

Az elmúlt évtizedben az intenzív patogenetikai alapkutatások eredményeként, az egyik leggyakoribb krónikus bőrbetegség definíciója megváltozott, pontosabbá vált. A pikkelysömör tehát szisztémás gyulladással járó, nem fertôzô, immunmediált betegség, melyre fokozott keratinocyta-proliferáció, parakeratózis, érelváltozások és immunológiai eltérések jellemzőek (4).

A patogenezis hátterében álló immunfolyamatok leírása a betegség kezelésének gyakorlatában is szemléletváltáshoz vezetett. Az új ismeretek az innovatív gyógyszergyártókat is új terápiás alkalmazások kifejlesztésére serkentették. Ezek eredményeként új gyógyszerek, a biológiai válaszmódosító szerek jelentek meg a piacon, és helyet követeltek maguknak a terápiás arzenálban. A biológiai szerekkel végzett klinikai vizsgálatok hasznos információval szolgáltak a hagyományos szisztémás gyógyszeres kezelés résztvevőirôl is. Az új ismeretek révén hazánkban is változás következett be a terápiás protokollokat tekintve (6).

Jelen vizsgálatunkban célul tûztük ki, hogy megvizsgáljuk, vajon a psoriasis pathomechanizmusának pontosabb megismerése milyen változásokat hozott a terápiás szokásokban.

Kutatásunk során három, idôben, vagy térben eltérô betegcsoport adatait elemezve érdekes megfigyelésként kijelenthetô, hogy a vizsgálati helytől, időtôl függetlenül, a betegek átlagéletkora, betegségük fennállásának ideje és a betegek nemi arányai csaknem azonosak voltak. A Magyarországon gondozott, rendszeresen szakorvos által kezelt psoriasisos populációról elmondható, hogy átlagéletkoruk 48-49 év, illetve, hogy enyhe férfi dominancia figyelhető meg, mely eredmény korrelál más vizsgálók adataival (7).

Fontos különbség, hogy a szakrendelôk betegei között magasabb volt az enyhe psoriasisban szenvedők aránya, ellentétben a centrum betegeivel, akik inkább középsúlyos-súlyos psoriasisban szenvedtek, sôt ez az arány csak fokozódott 2010-re a 2005-höz viszonyítva a centrumban (1. táblázat). Ez a súlyossági adat azonban csak az alkalmazott terápiák alapján lett megállapítva, hiszen a kezelés alatti PASI az aktuális státuszt mutatja, és meghatározásának kezelt betegeknél nincs információértéke a betegség kiindulási állapotára nézve. Ez az adat ugyanakkor bizonyos értelemben a terápiás szokásokra is utal, mely alapján kijelenthető, hogy egyrészt a klinikai centrumban és a szakrendelókben más a beteganyag, másrészt a centrumokban kisebb a lokális kezelések aránya, feltehetôen a hatékony szisztémás kezelések sikere miatt, és a szélesebb elérhető terápiás repertoár miatt. A nemzetközi adatok azt mutatják, hogy külföldön nincsenek ekkora különbségek az egyes járóbeteg-ellátó helyek terápiás beavatkozásai között, hisz például az Egyesült Államokban hasonló terápiás beavatkozási lehetőségekkel rendelkeznek az egyes bőrgyógyászati egységek, nincsenek a hazai ellátási értelemben vett centrumok (7). Hazánkban azonban a betegellátó rendszer progresszivitásából adódik, hogy egy centrumban valóban a lényegesen súlyosabb betegeket látják el.

Mindezek következménye, hogy sokkal nagyobb mértékû a lokális kezelés aránya a periférián, mint a centrumban, hisz az enyhébb súlyosságú betegeket gyakran elegendô helyi kezeléssel gyógyítani. Ha a másik irányból nézzük a folyamatot, akkor láthatjuk, hogy a helyi kezelés alkalmazása szignifikánsan csökkent a centrumban 2010re (2. táblázat). Ennek oka lehet, hogy magasabb arányban jelentek meg ebben a periódusban a centrumban a középsúlyos-súlyos klinikai tünetekkel rendelkező betegek, akiknél elsôsorban a szisztémás kezelések jelentették az elsôvonalbeli terápiát (a lokális kezelés csak kiegészítő terápia volt), és ezek hatékonysága mellett nem minden esetben van szükség helyi kezelésekre (8).

A fényterápia alkalmazásának arányát vizsgálva érdekes eredményt mutat a vizsgálat, miszerint vezető szerep jutott a szisztémás terápiák között a fénykezelésnek a 
centrumban 2005-ben, és a szakrendelőkben 2010-ben. A DEOEC 2010-es adatait vizsgálva szignifikánsan háttérbe szorult a fénykezelés alkalmazása (2. táblázat). Ennek az oka lehet, hogy a betegek igénye megváltozott a kezelések iránt, és az időigényes, logisztikailag gyakran megterhelő (pl. munkából való rendszeres kiesés) fényterápia helyett a gyógyszeres terápiát részesítették elônyben (8). Ugyanakkor a centrumokon kívül megjelentek egyéb fényterápiás egységek is, és ezek szintén csökkenthették a centrumok fényterápiára járó betegeinek számát, mivel esti órákban is a betegek rendelkezésére állnak.

A gyógyszeres terápiát vizsgálva is megfigyelhetô a hasonló alkalmazási tendencia a szakrendelők 2010-es és a centrum 2005-ös adatainak tekintetében. Mindkét esetben vezető szerep jutott az acitretinnek, ezt követte a methotrexát, és elhanyagolható volt a cyclosporin A terápiában részesülők aránya. Ennek magyarázata lehet, hogy az acitretin könnyen, hosszú ideig alkalmazható, mellékhatás profilja kedvező, illetve használata kombinálható a fénykezeléssel, és így effektivitása növelhető, ugyanakkor monoterápiában való kisfokú hatékonysága miatt az elmúlt években az európai ajánlások nem szerepeltetik az elsôként alkalmazhatóak között $(6,8)$. A centrum 2010-es adatait tudjuk szembeállítani az előzôekben felsoroltakkal. A már említett okok miatt jelentősen nôtt a középsúlyos-súlyos psoriasisosok aránya erre az időszakra, ezért csökkent a lokális terápia alkalmazásának aránya, és az új trendeknek megfelelően a gyógyszeres terápia került előtérbe. Azon belül is a methotrexát alkalmazása szignifikánsan nôtt ebben az időszakban, jelentősen megelőzve az acitretin, és a fénykezelés alkalmazásának arányát is. Hasonló tendencia látható egy 1990-2001 évek között végzett amerikai felmérésben, ahol a szisztémás terápiában a bôrgyógyászok által leggyakrabban használt lehetőség a methotrexát volt (36\%), majd ezt követte a fotokemoterápia (22\%), és végül az acitretin (7\%) (9). A legújabb európai ajánlás is a methotrexát elsővonalbeli szerként való alkalmazását javasolja (6).

A szisztémás terápiák alkalmazásának lassú növekedése, és a helyi kezelések lassú csökkenése figyelhető meg az 1996-2005 periódusban egy széleskörú amerikai vizsgálatban is (7). Itt 20 év (1985-2005) adataiban több mint 23 millió betegvizit eseményét dolgozták fel. Megállapították, hogy bár sokféle terápiás lehetôség volt elérhető az Egyesült Államokban, mégis a betegek nagy része elégedetlen volt a kezelésével. Mindez a kezelőorvosok részéról egy olyan változást hozott, hogy azok gyakrabban írtak fel szisztémás szereket a betegeknek a vizsgálat utolsó éveiben, mint annak kezdetén.

További érdekes változás a biológiai terápiák megjelenése. 2005-ben csak egyedi méltányosság alapján rendelhettük a centrumban súlyos állapotú, terápiarezisztens betegeknek a biológiai szereket, ezért csak a betegek 1\%-a részesült ebben a kezelésben. Ezen gyógyszerek felírása és kiadása, továbbra is csak biológiai terápiás centrumokban lehetséges (a DEOEC Bőrgyógyászati Klinika egyike a magyarországi 8 centrumnak). 2010-re szignifikánsan nôtt a biológiai szerek alkalmazásának aránya, sốt közvetlenül a methotrexát mögött, az acitretint, és a fénykezelést is megelőzve fontos szerepet töltöttek be centrumunk kezelési stratégiájában is. Bár „fiatal”, de nagyon hatásos készítmények, ezért hamar megtalálták helyüket a terápiás algoritmusban (10).

A nemzetközi irodalmat tovább vizsgálva, egy igen érdekes tanulmány számol be a psoriasis kezelési mintázatairól az Egyesült Államok bőrgyógyászati rendelőiben (11). A felmérés módszerei különböztek az általunk végzett módszerektôl. Az orvosi adatszolgáltatás mellett a betegek is töltöttek ki kérdôívet. Csaknem 900 beteg adatait dolgozták fel. A betegek átlagéletkora (46 év), és a nemek aránya (enyhe férfi dominancia) hasonló képet mutatott, mint magyarországi saját adataink. Az enyhe, illetve középsúlyos-súlyos betegek arányáról nem szolgáltattak adatokat, de a vizsgált populációt nézve magas arányban fordult elô a lokális terápia alkalmazása, és a szisztémás terápiában a biológiai szereket részesítették előnyben, majd ezt követte a hagyományos gyógyszeres terápia, és végül a fénykezelés. Bár a lényeges különbségek háttere természetesen az eltérô egészségügyi támogatási rendszerben is keresendő, mégis a centrum 2010es adataihoz igen hasonló mintázat olvasható le az amerikai adatokból is (11).

Összefoglalva elmondható, hogy a hipotézisünk igazolódott, és a psoriasis klinikai definíciójának megváltozása és a pathogenezisének részletesebb megismerése valóban jelentôs, szignifikáns változásokat hozott a betegség kezelési algoritmusában. Az alapkutatások tehát már nem a távoli jövő gyógyszereinek alkalmazási lehetôségeit vetik fel, hanem olyan adatokat szolgáltatnak, melyek alapján a ma gyógyszereit biztosítják ebben a súlyos, krónikus, szisztémás betegségben szenvedő betegeknek.

A vizsgálat elvégzéséhez az OTKA 81381 és a TÁMOP 4.2.2.A11/1/ KONV-2012-0023 „VÉD-ELEM” pályázat (Új Magyarország Fejlesztési Terv és European Social Fund and European Regional Developmet Fund) nyújtott segítséget.

\section{IRODALOM}

1. Mrowietz U., Kragballe K., Reich K. et al.: Definition of treatment goals for moderate to severe psoriasis: a European consensus. Arch Dermatol Res (2011) 303, 1-10.

2. Cargill M., Schrodi S.J., Chang $M$ et al.: A large-scale genetic association study confirms IL12B and leads to the identification of IL23R as psoriasis-risk genes. Am J Hum Genet (2007) 80, 273-90.

3. Reich K., Mossner R., Konig I. R. et al.: Promoter polymorphisms of the genes encoding tumor necrosis factor-alpha and interleukin-1beta are associated with different subtypes of psoriasis characterized by early and late disease onset. J Invest Dermatol (2002) $118,155-63$

4. Koo J., Lee E., Lee C. S. et al.: Psoriasis. J Am Acad Dermatol (2004) 50, 613-22.

5. Gyulai R., Kemény L.: A pikkelysömör immunológiája: Az alapkutatástól a betegágyig. Orv Hetil. (2006) 147, 2213-20.

6. Pathirana D., Ormerod A. D., Saiag P. et al.: European S3-guidelines on the systemic treatment of psoriasis vulgaris. J Eur Acad Dermatol Venereol (2009) 23 Suppl 2, 1-70. 
7. Strowd L. C., Yentzer B. A., Fleischer A. B., Jr. et al.: Increasing use of more potent treatments for psoriasis. J Am Acad Dermatol (2009) 60, 478-81.

8. Szegedi A.: A pikkelysömör kezelési lehetőségei (kivéve biológiai terápiák). Háziorv Továbbképző Szemle (2009) 14, 31-6.

9. Pearce D. J., Stealey K. H., Balkrishnan R. et al.: Psoriasis treatment in the United States at the end of the 20th century. Int J Dermatol (2006) 45, 370-4.
10. Gáspár K.: A psoriasis biológiai terápiája Háziorv Továbbképzô Szemle (2011) 16, 470-3.

11. Patel V., Horn E. J., Lobosco S. J. et al.: Psoriasis treatment patterns: results of a cross-sectional survey of dermatologists. J Am Acad Dermatol (2008) 58, 964-9.

Érkezett: 2013. 05. 10

Közlésre elfogadva: 2013. 05. 17.

\section{„Fekete Zoltán” tudományos kutatási pályázat, 2013}

Az Alapítvány ez évi kutatási pályázatára 2013. október 11-én éjfélig postára adott, vagy október 15-én 15.00 óráig egyéb módon (pl. személyesen, küldönccel) eljuttatott, a 2012-2013. évek folyamán már megjelent, vagy igazoltan publikálásra elfogadott dolgozatokkal (egy, vagy több múvel) lehet pályázni. A pályázat a bőr- és nemi gyógyászat, kozmetológia, továbbá e szakmák határterületeinek (pl. dermatoallergológia, STD kórképek, andrológia, phlebológia, onkológia, mikológia, bőrsebészet, sebgyógyulás stb.) témáiban, lektorált szaklapokban megjelenő angol, német, francia, vagy magyar nyelvû publikációk 5 példányban történő benyújtásával történik. Könyvet, monográfiát nem fogadunk el. (cím: ÁEK Bőrgyógyászati Osztály 1062 Budapest, Podmaniczky u. 109-111; Tel.: 1-475-2628). A faxon, diszken, e-mailen érkezett anyagokkal nem áll módunkban foglalkozni. A több szerzős dolgozatok esetében a társszerzők nyilatkozata szükséges, amelyben egyetértenek a pályázati szándékkal, támogatva a pályázatot benyújtó személyt.

A pályadíjat, melynek összege 680,- Euro, a Bíráló Bizottság által titkos szavazással a legjobbnak ítélt pályamú fogja elnyerni.

A Bizottság (mely a klinikai tanszékvezetókbool, és a Kuratórium elnökéből áll) döntését november elején a Kuratórium elé terjeszti, amely a pályázat eredményét a MDT 2012. évi Nagygyúlésen hirdeti ki.

A győztes e Fórumon eredményeirôl előadás formájában számol majd be, melynek időpontját a programban előre kijelöli a tudományos bizottság.

Prof. Dr. Baló-Banga J. Mátyás főorvos, a Kuratórium elnöke

MH Honvédkórház

Budapest 